\title{
Whiplash associated disorders
}

Citation for published version (APA):

Verhey, F. R. J., Stapert, S. Z., \& Jolles, J. (1999). Whiplash associated disorders: Is there a place for psychiatrists and psychologists? Acta Neuropsychiatrica, 11, 134-136.

https://doi.org/10.1017/S0924270800035882

Document status and date:

Published: 01/01/1999

DOI:

10.1017/S0924270800035882

Document Version:

Publisher's PDF, also known as Version of record

\section{Please check the document version of this publication:}

- A submitted manuscript is the version of the article upon submission and before peer-review. There can be important differences between the submitted version and the official published version of record.

People interested in the research are advised to contact the author for the final version of the publication, or visit the DOI to the publisher's website.

- The final author version and the galley proof are versions of the publication after peer review.

- The final published version features the final layout of the paper including the volume, issue and page numbers.

Link to publication

\footnotetext{
General rights rights.

- You may freely distribute the URL identifying the publication in the public portal. please follow below link for the End User Agreement:

www.umlib.nl/taverne-license

Take down policy

If you believe that this document breaches copyright please contact us at:

repository@maastrichtuniversity.nl

providing details and we will investigate your claim.
}

Copyright and moral rights for the publications made accessible in the public portal are retained by the authors and/or other copyright owners and it is a condition of accessing publications that users recognise and abide by the legal requirements associated with these

- Users may download and print one copy of any publication from the public portal for the purpose of private study or research.

- You may not further distribute the material or use it for any profit-making activity or commercial gain

If the publication is distributed under the terms of Article $25 \mathrm{fa}$ of the Dutch Copyright Act, indicated by the "Taverne" license above, 


\title{
Whiplash associated disorders: is there a place for psychiatrists and psychologists?
}

\author{
F.R.J. Verhey, S.Z. Stapert, J. Jolles
}

\section{Summary}

Between 25 and $30 \%$ of the victims of a whiplash injury have complaints after one vear. This condition is referred to as late whiplash syndrome. This syndrome is characterized by pain of the neck, headache, forgetfulness, poor concentration, mental fatigue, and affective symptoms. The causes of the persistent symptoms are unknown. In all, the evidence that late-whiplash syndrome is a neurological disorder is flimsy. Current opinion holds that the acute basis is the painful injury of the neck. In the months following the accident, pain is the substrate on which psychological and social factors may act. Emotional symptoms such as lability of affect and disturbed mood, or posttraumatic stress disorders are common after whiplash. Although there is definitely a place for psychiatrists and psychologists in the treatment of late whiplash syndrome, these professionals are not involved in late whiplash disorder as much as they should be. Brief psychological treatment has proven to significantly reduce the severity and duration of symptoms. Optimal management must cover the treatment of pain, depression, anxiety, and fatigue; adequate psycho-education, stressing the good long-term outcome; and education of patients and relatives on possible cognitive symptoms. Acta Neuropsychiatrica 1999, 11: 134-136

\section{$\mathrm{W}$} hiplash is a common term for sprain and strain of the cervical region caused by a sudden and forceful flexionextension movement, typically as a result of rear-end collisions in traffic. This may result in bone and soft tissue damage, which can give rise to complaints of neck pain, headache, radiation pain in the arm, or paresthetic symptoms. Though the layman's perception of whiplash often suggests that this condition leads to a severe and chronic pattern of symptoms, whiplash is usually a benign condition with a fairly good rate of recovery and a lack of identifiable physical or neurological damage. ${ }^{\prime}$ In most patients signs and symptoms resolve within a few weeks or months, and most patients are asymptomatic by six months. However, a minority of patients, estimated at 25-30\%, have persistent or worsening complaints after one year. This condition is referred to as the late-whiplash syndrome. Patients with late-whiplash syndrome experience various symptoms, including pain of the neck, headache, forgetfulness, poor concentration, mental fatigue, and affective symptoms. Patients with late whiplash disorders are often reluctant to visit psychiatrists or psychologists because they fear that these professionals will confirm that their complaints are 'psycho-

Correspondence address:

Dr. F.Verhey, M.D., Ph.D.

Institute of Brain and Behavior, Department of Cognitive Disorders Academic Hospital of Maastricht, Department of Psychiatry

Post box 5800

6202 AZ Maastricht

The Netherlands logical' and will deny that there is a physical basis for their complaints. In this article, we focus on the question whether, and to what extent, late whiplash syndrome can be regarded as a disorder of the brain, the body, or the mind. We determine the contribution that contemporary psychiatry and (neuro)psychology can make to treatment strategies.

\section{LATE WHIPLASH SYNDROME: DOES IT REALLY EXIST?}

The causes of the persistent symptoms are unknown, and there is little or flimsy evidence for a structural basis for chronic whiplash. ${ }^{2}$ The number of scientific studies is small, and as a consequence, there are still no evidencebased guidelines for diagnosis and treatment. For this reason, clinicians wonder whether this syndrome is based on reality or on fiction. ${ }^{3}$ The answer to this question determines the clinician's attitude toward the patient with signs and symptoms of late whiplash syndrome: does he (or she) acknowledge the needs and suffering of the patient, and he (she) explain the patients behavior? Or does he (she) confine him (her)self to what is considered proven, by stating that "no disorders can be found in his domain of expertise'.

The answers to these questions also depend on what can be regarded as 'real'. Several answers are possible. In the first place, the question refers to a methodological issue, i.e. whether the symptoms are objectifiable and measurable, thus enabling a scientific approach. Late whiplash syndrome is not a clear entity in the traditional nosological sense. We still do not know how to diagnose and to measure the syndrome reliably. Objective (i.e.: biological) diagnostic markers are lacking. However, this situation is not unusual in psychiatry, in which most disorders are defined as clusters of more-or-less subjective signs and symptoms. This does not imply that the syndrome does not exist, although it may mean that it cannot readily be explained in terms of a traditional, substrate- oriented medical model.

In the second place, the question is whether late whiplash syndrome is a recognizable cluster of symptoms. There is circumstantial evidence to consider that it is. Several epidemiological studies have shown that a minority (about 25-30\%) of patients complain of a more-or-less circumscript cluster of symptoms one year after whiplash trauma. ${ }^{2,4,5}$ In a follow-up study of more than thousand patients who had a whiplash trauma, 300 still had somatic, cognitive, and emotional complaints after six months. The profile of complaints may vary from one patient to the other. Radanov and coworkers have suggested that 
there may be two discernible clusters: a low cervical spine syndrome, in which pain in the neck, head, and arms dominate the clinical picture. and a "cervico-encephalic syndrome". characterized by psychological symptoms, dizziness, tiredness. disturbed concentration. and photophobia."."

In the third place, the question whether late whiplash is real can be considered in a normative waly. Chronic whiplash is often discussed in the context of legislation and financial compensation. In this regard, a recent study performed in Lithuania drew considerable attention. The study, titled: Natural evolution of late whiplash syndrome outside the medicolegal context', reported that the frequency of occurrence of chronic neck pain and headache was similar among victims of rear-end collisions and among controls who were uninjured. Compensation was believed to be the crucial factor. Although this conclusion raised serious criticism, " the study was (and is still) frequently cited in the scientific literature and in the media. The implicit message seemed to be that late whiplash syndrome is not a real disorder, because it lacks physical injury and because its origins are psychological. To consider chronic pain after a car accident as a process that can be understood in psychological terms may lead to underevaluation of the consequences as not being real'. Patients react to this by stressing the physical nature of their complaints and by denying psychological mechanisms. This may, in turn, constitute the basis of what we have called an iatrogenic accident neurosis. ${ }^{10}$ Clearly, a more integrated approach than the traditional dualistic one is warranted, in which findings from both somatic medicine and psychology are combined. The question whether late whiplash is 'real' should be rephrased as: is the clinician convinced that the complaints of the patient are a sincere and true expression of 'real' suffering. It is not possible to give a general answer to this question because the circumstances are different for each patient.

\section{IS WHIPLASH A BRAIN DISORDER?}

There is continuing debate on whether late whiplash syndrome should be regarded as a primary somatic disorder, and if so, whether it is a brain disorder or not. In a recent review, Alexander discussed this issue on the basis of available evidence. " In the following paragraphs, we summarize his paper, which is highly recommended for further reading.

Chronic whiplash patients complain of cognitive symptoms, which suggests that a mild traumatic brain injury is present. It has been shown that pure deceleration force to the brain can produce diffuse axonal injury in nonhuman primates. ${ }^{12}$ This was especially the case in monkeys which were comatose for 15 minutes or longer. The amount of diffuse axonal injury paralleled the severity of injury, as measured by the duration of coma, neurological signs, and outcome. "Mild brain injury in humans with an amnesia of 30 minutes can produce modest diffuse axonal injury, as visualized by MRI scanning. However, there is no evidence so far in the literature that humans who do not lose consciousness have the same brain lesions.

It could be argued that more sensitive measures of brain function may be able to demonstrate brain damage. Over the last years. a high prevalence of abnormal SPECT and PET findings has been reported in individuals with mild brain injury or whiplash, especially hypoperfusion in the frontal and anterior temporal regions. ${ }^{13-15}$ The sophisticated magnetic transfer technique has detected abnormalities in patients with late sequelae of mild brain injury. ${ }^{16}$ However, since these abnormalities on SPECT or MRI may also be present in patients who recover completely from trauma, they do not prove a relationship with neurological disability. Similar SPECT findings have also been reported in patients with depression but without a history of whiplash. In all, there is little evidence that late-whiplash syndrome is a neurological (i.e. brain) disorder.

\section{THE PATHOGENESIS OF LATE WHIPLASH SYN- DROME}

If the evidence for a neurological basis for late whiplash is weak, what then is its pathogenesis? Somatic-oriented specialists often seem to adhere the psychogenic viewpoint and vice versa. In a recent editorial in the Journal of Rheumatology, rheumatologists emphasized the psychological aspect. while a psychiatrist highlighted the physical aspects. ${ }^{9,17.18}$ The search for an organic (biological) disease on the one hand and a psychiatric problem or disease (nonorganic) on the other is gradually making place for explanations of late whiplash syndrome in terms of a multidimensional or biopsychosocial model. ${ }^{19}$ The aches and pain of the head and neck 3-6 weeks after injury may evolve into the late whiplash symptom complex. To label patients with symptoms and disabilities after six months as suffering from 'chronic whiplash' implies continuing disease caused by their injury. A notion which bears promise in evaluating the relative contribution of somatic factors is the concept of vulnerability factors. ${ }^{20}$ Current opinion holds that the acute basis is the painful injury of the neck. Factors that predict a poor prognosis are closely related to pain; radicular injury, intense neck pain directly after the injury, but also pre-existent degeneration of the cervical vertebrae and pre-existent headache. In the months following the accident, pain is the substrate on which psychological and social factors may act. In this respect, the term 'somatopsychic' is more appropriate than 'psychosomatic'.21 The three components of late-whiplash symptomatology, i.e. pain, depression, and disturbed cognition, reinforce each other. There is a close interrelationship between chronic pain and depression. Depression is often accompanied by cognitive dysfunction. Patient expectations or understanding of the meaning of cognitive symptoms may generate some of the psychological reaction. ${ }^{22}$ The 
painthreshold is directly influenced by depression. 2.3 Hypervigilance for cognitive symptoms by relatives and physicians may lead to a premature diagnosis. Inadequate treatment of pain and the development of anxiety or depression may leave patients at risk for secondary psychogenesis. ${ }^{11}$ In addition, the pain often results in reduced effectiveness of sleep. Neurocognitive symptoms can be the result, which further compromise coping behaviour and lead to additional psychological problems. This and other facets of being an accident victim in some cultures also promote symptom amplification.

\section{THE ROLE OF PSYCHIATRIST AND PSYCHOLOGISTS}

Without convincing neurological or radiological evidence of structural damage in whiplash injuries, it is a challenge for psychiatrists and psychologists to prevent and treat the chronic pain and suffering encountered. Indeed, emotional symptoms such as lability of affect and disturbed mood are common after whiplash. 24.25 Symptoms of post-traumatic stress disorder are also not rare after an accident involving a patient who was fully conscious at the time. Patients can give an impressive account of their intense emotional experiences during the collision, and may frequently have phobic reactions and nightmares or show avoidance behavior. Thus, the place for psychiatrists and psychologists seems obvious. However, psychiatrists are not involved in late whiplash disorder as much as they should be, at least in the Netherlands. So far, designing professional guidelines for whiplash is not a very high priority for the Dutch Society of Psychiatry. Psychiatrists are thus forced in the undesirable situation of having to use the guidelines of the Society of Neurology, which place little emphasis on psychiatric and psychological aspects.

The dualistic models were wrong and are fortunately being abandoned because they increase the risk that potential treatment options are left unused. Brief psychological treatment has proven to significantly reduce the severity and duration of symptoms following mild head trauma, ${ }^{26.27}$ and psychiatric treatment of depression and anxiety following whiplash or mild traumatic brain injury looks promising. These disciplines seem better equipped to offer a solution for late whiplash syndrome than the treatment of the possible neurological consequences. "As the search for biological markers will go on, optimal management must cover the treatment of pain, depression, anxiety, and fatigue; adequate psychoeducation, stressing the good long-term outcome; and education of patients and relatives on possible cognitive symptoms.

\section{L.iterature}

1. Radanov BP. Sturzenceger M. DiStefanu G. Longterm autcome after whiplash injury: a 2 year follow-up considering teatures of injury mechanism and somatic. radologic, and psychosocial findings. Medicine 1945: 74: 281-97.

2. Pearce JMS. Polemics of shronic whiplash injury. Neurology 1994: 44: 1993-7.

3. Wijngaarden GKv'. Het late "whiplash-syndroom": realiteit of fictie? Ned Tijdschr Geneenk 1991: 135: 279-83.

4. Norris $\mathrm{SH}$, Watt 1 . The prognosis of neck-injuries resulting from rear-end vehicle collusions. Journal Bone Joint Surg [Br] 1983: 65B56-A: 608-11.

5. Pearce JMS. Whiplash injury: a reappraisal. J Neurol Neurosurg Psychiatry 1989:52: 1329-31.

6. Radanov BP, Dvorak J, Valach L. Cognitive deficits in patients after soft tissue injury of the cervical spine. Spine 1992; 17:127-31.

7. Radanov B, Stefano GD, Schindrig A, Ballinari P. Role of psychosocial stress in recovery from common whiplash. Lancet 1991; 338: $712-15$.

8. Schrader H, Obelieniene D, Bovim G, et al. Natural evolution of late whiplash syndrome outside the medicolegal context. Lancet 1996; ii: $1207-11$.

9. Radanov BP. Common whiplash- research findings, J Rheumat 1997; 24: 623-5.

10. Verhey FRJ. Post-Whiplash syndroom. Ned Tijdschr Geneesk 1991: 135: 678 .

11. Alexander MP. In the pursuit of proof of brain damage after whiplash injury. Neurology 1998; 51:336-40.

12. Gennarelli TA, Thibault LE, Adams JH, Graham DI. Thompson CJ, Marcinin RP. Diffuse axonal injury and traumatic coma in the primate. Neurology $1982 ; 12: 564-74$.

13. Jacobs A. Put E, Ingels M, Put T, Bossuyt A. One-year follow-up of technetium-99-m-HMPAO SPECT in mild head injury. Eur J Nucl Med 1996; 37: 1605-9.

14. Otte A. Ettlin T. Fierz L. Mueller-Brand J. Parieto-occipital hypoperfusion in late whiplash syndrome: first quantitative SPET study using technetium-99-m bicisate (ECD). Eur J Nucl Med $1996 ; 23: 72-4$.

15. Bicik I, Radanov BP, Schäfer N, et al. PET with 18-fluorodeoxyglusoe and hexamethylpropylene amine oxime SPECT in late whiplash syndrome. Neurology 1998: 51: 345-50.

16. Hofman P, Verhey FRJ, Rozendaal N, Jolles J, Wilmink JT. Brain lesions in patients with post-concussional sequelae after mild head injury. (Proceedings of the XXII Congress of the European Society of Neuroradiology). Neuroradiol 1996; 38: 125.

17. Gordon DA. The rheumatologist and chronic whiplash syndrome. J Rheumatol 1997; 24: 617-8.

18. Ferrari R, Russell AS. The whiplash syndrome-common sense revisited. J Rheumatol 1997; 24: 618-23.

19. Ferrari R, Russell AS. Whiplash: heading for a higher ground. Spine 1999; 24: 97-8.

20. Jolles J, Verhey FRJ, Riedel WJ, Houx PJ, Cognitive impairment in elderly people: predisposing factors and implications for drug therapy. Drugs and Aging 1995: 7: 459-79.

21. Lishman WA. Physiogenesis and psychogenesis in the post-concussional syndrome. Br J Psychiatry 1988; 153: 460-9.

22. Mittenberg W, DiGiulo DV. Perrin S, Bass AE. Symptoms following mild head injury: expectation as etiology. J Neurol Neurosurg Psychiatry 1992; 55: 200-4.

23. Lee J, Giles K, Drummond PD. Psychological disturbances and an exaggerated response to pain in patients with whiplash injury. J Psychosom Res 1993: 37: 103-10.

24. Verhey FRJ. Zit whiplash tussen de oren? Verkeersrecht 1998; 7 I 8: 194-6.

25. Stapert SZ. Jolles J. Neuropsychologische aspecten van het whiplashletsel. Verkeersrecht 1998: 7/8: 202-4.

26. Miller W, Mittenberg W. Bief cognitive behavioral interventions in mild traumatic head injury. Applied Psychology 1998; 5: 172. 83 .

27. Ponds RWHM. Schmidt AJM, Lugt Md, Lulofs R, Verhey FRJ, Jolles $J$. De angst om te vergeten: behandeling van functionele geheugenklachten. Tijdschr Psychiatr 1995; 37: 62-8. 